\title{
Dociekania
}

\section{Przegapiona okazja}

Danuta Ulicka
Artykuł powstał w ramach projektu badawczego $\mathrm{NCN}$ 2014/13/B/HS2/oo310 Wiek teorii. Sto lat polskiej myśli teoretycznoliterackiej.

TEKSTY DRUGIE 2018, NR 6, S. 217-230

DOI: $10.18318 /$ td.2018.6.16

B ez narodowej megalomanii, bijącej z XVII-wiecznego traktatu Wojciecha Dembołęckiego O tym, że najdawniejsze w Europie jest Królestwo Polskie, a język słowieński pierwotnym językiem świata, nie inaczej niż z pogardy dla "lenistwa umysłowości cudzoziemskiej"1 - równie prowincjonalnych, jak wielokrotnie powtarzane za Słowackim oskarżenia kultury polskiej o "pawi” i "papuzi” charakter, „ciurowatość" , wytwór narodu „nieudaczników", których stygmatyzuje "podświadome poczucie faktycznej niższości, połączone ze świadomym dodęciem się do żądanego poziomu"”, także bez wdawania

1 J. Ujejski Polska jako przedmiot nauk humanistycznych, "Nauka Polska” 1920 t. 3 . O dumie narodowej nie masz pracy bogatszej w przykłady i wnikliwe historyczne diagnozy niż Jana Stanisława Bystronia Megalomanja narodowa:źródła - teorje - skutki, Gebethner i Wolf, Warszawa 1924.

2 K. Irzykowski Plagiatowy charakter przełomów literackich w Polsce [1922], przedr. w: tegoż Słoń wśród porcelany. Lżejszy kaliber, red. A. Lam, Wydawnictwo Literackie, Kraków 1976, s. 36. W nawiasy kwadratowe ujmuję datę pierwodruku.

3 S.I. Witkiewicz O artystycznym teatrze [1938], w: tegoż Teatr i inne pisma o teatrze, red. J. Degler, PIW, Warszawa 1995, s. 272.
Danuta Ulicka - prof. zw. dr hab., kierownik Zakładu Poetyki, Teorii Literatury i Metodologii Badań Literackich w IPL UW. Jej ostatnia książka to Słowa i ludzie. 10 szkiców z antropologii filologicznej (2013).

Zainteresowanie narodzinami teorii, czyli literaturoznawstwem nowoczesnym w Europie Środkowej iWschodniej, potwierdza własnymi przekładami z klasycznej humanistyki rosyjskiej i ich inicjowaniem w seriach wydawniczych. Kontakt: danutaulicka@poczta.onet.pl 
się w dywagacje, czy w historii nauki prekursorstwo tylko tyle „znaczy, że gdzieś, komuś, ślepej kurze udało się znaleźć ziarnko, a kto inny później [...] wyhodował drzewo"4, czy też na odwrót: liczy się tylko odkrycie, a nie jego powtórzenie, rozwinięcie bądź cyzelowanie - bez roztrząsania tych i podobnych kwestii ogólnych i pobocznych, powiem bez ogródek: wielu międzywojennym i powojennym koncepcjom literaturoznawczym sformułowanym przez badaczy polskich trzeba przyznać oryginalność i właśnie prekursorstwo (nieanachroniczne) ${ }^{5}$ wobec koncepcji powszechnie w świecie uznawanych za autorytatywne i kanonicznych. Pominę tu ich wykaz ${ }^{6}$, bo ważniejsze wydaje się pytanie, czemu odkrywcze hipotezy i teorie, artykuły i rozprawy - opublikowane w językach nieperyferyjnych choć nie ustępowały tym, które weszły do światowego kanonu, były od nich niezależne i zwyczajnie wcześniejsze, w kanonie tym się nie znalazły. Czemu „przeczuliśmy, wyprzedziliśmy i nic z tego nie wyszło"??. Dlaczego polskie literaturoznawstwo nowoczesne nie zaistniało jako fakt, liczący się w międzynarodowej naukosferze, porównywalny z takimi faktami jak Russkaja tieorija, Česká teorie, French Theory, Anglo-American New Criticism? Choć nie było ani prowincjonalne, ani peryferyjne, nie podlegało ani spychającym na pozycję półperyferyjną zależnościom kompradorskim, ani samokolonizacji bądź samoorientalizacji ${ }^{8}$. Trzeźwo patrząc, dobrowolnie samoskolonizowały się raczej badania literackie amerykańskie i francuskie, twórczo naśladowcze najpierw wobec rosyjskiego formalizmu i czeskiego strukturalizmu, a potem Bachtina, który w ogóle od lat 8o. podporząadkował sobie znaczne połacie humanistyki światowej. Tym - jakoś nikt „samokolonizacji" nie wytyka.

4 K. Irzykowski Ząb za ząb, „Wiadomości Literackie” $1927 \mathrm{nr} 14$.

5 Odwrócona formuła Konstantego Jeleńskiego, ironizującego nad „prekursorami anachronicznymi" (K. Jeleński Prekursor anachroniczny [1961], w: tegoż Szkice, red. W. Karpiński, Znak, Kraków 1990, s. 231.

6 O niektórych pisałam w artykule Jak być dobrym historykiem (nauki o literaturze polskiej)?, w: Literatura prze-pisana II, red. A. Izdebska, A. Przybyszewska, D. Szajnert, Wydawnictwo Ut, Łódź 2016.

7 S. Zahorska Psychoanaliza faszyzmu [1944], w: Psychoanaliza w Polsce 1909-1946, t. 2, red. L. Magnone, Fundacja Augusta hrabiego Cieszkowskiego, Warszawa 2016, s. 349.

8 T. Glanc Orientalismus a sebeorientalizace, "Česka Literatura” $2009 \mathrm{nr}$ 6; T. Zarycki Polskie nauki społeczne w świetle hipotezy peryferyjnej dualności, "Zagadnienia Naukoznawstwa” 2013 nr 1 (195); A. Kiossev [1998] Metafora samokolonizacji, przeł. I. Ostrowska "Czas Kultury" 2016 nr 4. 
Socjologowie wiedzy, podobnie jak socjologowie niewiedzy (agnotologowie) ${ }^{9}$, analizujący złożone procesy wiedzotwórcze, które prowadzą do powstania, rozpowszechniania i utrwalania autorytetów w nauce i osiągania naukowych sukcesów, ich transferów i retransferów, wskazują na istotną rolę mechanizmu reprodukcji ${ }^{10}$. Inercyjne powtarzanie utrwalonych ujęć prowadzi do „efektu Mateusza”"1 i powstawania naukowych imaginariów, kształtujących silne dyspozycje poznawcze. Ich nośnikiem są krążące w świecie, najczęściej cytowane kompendia propedeutyczne: encyklopedie, podręczniki i antologie oraz wzięte (zwykle pierwsze) monografie. I właśnie w tym doksograficznym pejzażu polskie literaturoznawstwo teoretyczne było i jest praktycznie nieobecne. Najlepiej to widać w porównaniu z teoriami sąsiedzkimi, rosyjską i czesko-słowacką, powszechnie uznawanymi za założycielskie dla dyscypliny i wciąż przywoływanymi - jako jedyne ${ }^{12}$.

9 Socjologię niewiedzy, zaprojektowaną w 1975 roku (D. Weinstein, M.A. Weinstein The Sociology of Nonknowledge: A Paradigm, "Research in Sociology of Knowledge, Sciences \& Art” 1975 vol. 1, s. 151-166) i wiedzy odrzuconej (On the Margins of Science: The Social Construction of Rejected Knowledge, ed. by R. Wallis, University of Keele, Staffordshire 1979) scalił i oparzył mianem „agnotologia" w roku 1995 Robert N. Proctor. Jej założenia obszernie przedstawił we wstępie Agnotology: A Missing Term to Describe the Cultural Production of Ignorance and its Study do zbioru The Making and Unmaking of Ignorance, ed. by R.N. Proctor, L. Schiebinger, Stanford University Press, Stanford 2008. Proctora interesują przede wszystkim mechanizmy ideologiczno-ekonomiczne wytwarzania ignorancji, innych badaczy - także geopolityczne (W.D. Mignolo The Geopolitics of Knowledge and the Postcolonial Diffrence, „Social Epistemology” 2005 No. 19, s. 111-127). Zaawansowane badania nad kulturami niewiedzy prowadzone są od 2005 roku na Uniwersytecie w Augsburgu, w ramach projektu „Nichtwissenskulturen”. W Polsce o polach zainteresowań agnotologii pisali: M. Czyżewski Społeczeństwo niewiedzy i socjologia niewiedzy, w: Kreowanie społeczeństwa niewiedzy, red. A. Jabłoński, J. Szymczak, M. Zemło, Wydawnictwo KUL, Lublin 2015; R. Sojak, D. Wicenty Zagubiona rzeczywistość. O społecznym konstruowaniu niewiedzy, Oficyna Naukowa, Warszawa 2005. Agnotologia wydaje się spokrewniona z koncepcją znaną w historiografii i antropologii historii pod nazwą imputacji kulturowej (W. Wrzosek O myśleniu historycznym, Oficyna Wydawnicza Epigram, Bydgoszcz 2009, s. 7 i 14; L. Kwiatkowska-Frejlich Imputacja kulturowa w polskiej historiografii sztuki 1975-1863, Wydawnictwo UMCS, Lublin 2014, s. 8).

P. Bourdieu, J.-C. Passeron Reprodukcja, Elementy teorii systemu nauczania [1970], przeł. E. Neyman, PWN, Warszawa 1990; J. Goćkowski Autorytety społeczeństwa uczonych, PW, Wrocław 1979.

11 R. Merton The Matthew Effect in Science, "Science” 1968 No. 159 (http://www.garfield.library. upenn.edu/merton/matthew1.pdf). Merton sformułował swoje prawo, odwołując się do słów z Ewangelii według św. Mateusza: „Albowiem temu, kto ma, będzie dane i obfitować będzie; a temu, kto nie ma i to co, co ma, będzie odjęte" (Mat. 13,12), z których wyprowadził zasadę utrwalania autorytetów w nauce.

12 Polska teoria literatury nie funkcjonuje ani w podręcznikach, ani w antologiach światowych badań literackich. Dość zauważyć, że w fundamentalnej wielotomowej The Cambridge Histo- 
Te kształtujące dyspozycję literaturoznawczą wzorotwórcze kompendia, które obrysowały kontur nowoczesnej teorii, powstawały pod koniec bojowego okresu literaturoznawstwa środkowo-i wschodnioeuropejskiego najpierw w latach 40.i 50. w USA. Były naonczas nie tylko pierwsze, ale i jedyne, musiały więc uzyskać światowy rezonans. To one ustaliły kanon „teorii literatury” - jej definicję, wykładnię reprezentujących ją szkół: rosyjskiego formalizmu i czeskiego strukturalizmu, na których marginesie pojawiała się okazjonalnie Ingardenowska fenomenologia, listę teoretyków i korpus kanonicznych tekstów nieodmiennie wypełniających antologie. „Krążące referencje”13 ten kanon i korpus ustabilizowały; od lat 6o., kiedy został powielony w Europie Zachodniej (najpierw we Francji, a potem w Niemczech i Wielkiej Brytanii), $\mathrm{z}$ niewielkimi zmianami funkcjonują one do dziś, reprodukowane w kolejnych zbiorach „fabrykujących teorię"14.

Cuius memoria,eius victoria - by podsumować.

Wzorotwórcze kompendia pisali literaturoznawcy - emigranci z Europy Środkowej i Wschodniej i ich uczniowie z pierwszej, jeszcze przedwojennej

ry of Literary Criticism, w tomie 8: From Formalism to Poststructuralism, ed. by R. Selden, Cambridge Univeristy Press, Cambridge 1995, w rozdziale poświęconym strukturalizmowi omawiany jest wyłącznie strukturalizm praski, a tylko w bibliografii - i to w Secondary sources, do tego pod skróconym, zniekształcającym koncepcję autora tytułem - wymieniony został jedynie Janusz Sławiński jako autor Literatur als System (poprawny tytuł: Literatur als System und Prozess: strukturalistische Aufsätze zur semantischen, kommunikativen, sozialen und historischen Dimension der Literatur, ausgew. übers. komment. und eingel. von R. Fieguth, Nymphengurger Verlagshandlung, München 1975). Nie jest też odnotowywane w monografiach, w których po samych tytułach należałoby się tego spodziewać (jak S. Cassedy Flight from Eden: The Origins of Modern Literary Criticism and Theory, University of California Press, Berkeley 1990). Są nie do zlekceważenia, oczywiście, uwagi o polskich teoriach i teoretykach rozproszone w różnych pracach: w artykułach Romana Jakobsona, w monografiach Victora Erlicha (Russian Formaslim: History - Doctrine, 's Mouton, Gravenhage 1955) i Endre Bojtára (Slavic structuralism, transl. H. Thomas, Akadémiai Kiadó, Budapest 1985) ani pojedyncze monografie kierunków (A. Karcz Polish Formalist School and Russian Formalism, University of Rochester Press, Rochester-New York 2002) - ale nie równoważą one nadobecnych teorii rosyjskiej i czesko-słowackiej. W ostatniej dekadzie nawet w pracach życzliwych slawistów poświęconych literaturoznawstwu środkowo- i wschodnioeuropejskiemu o polskim nie napomyka się ani słowem (por. C. Emerson Answering for Central and Eastern Europe, w: Comparative Literature in an Age of Globalization, ed. by H. Saussy, Johns Hopkins University Press, Baltimore 2006, s. 203-211.

13 B. Latour Nadzieja Pandory: eseje o rzeczywistości w studiach nad nauka [1999], przeł. K. Abriszewski, Wydawnictwo Naukowe UMK, Toruń 2013, s. 55. 
i wojennej fali, a potem kolejni uchodźcy i uciekinierzy ${ }^{15}$. Pod tym względem nasza „mała", by ją tak nazwać, literaturoznawcza emigracja była i stosunkowo nieliczna, i słaba, a i chyba źle poruszała się po nowych rynkach naukowych. W przeciwieństwie do literaturoznawstwa rosyjskiego i czeskiego, które od początku miało silnych ambasadorów w USA, Kanadzie, Francji, Izraelu (takich jak Roman Jakobson, Viktor Erlich, René Wellek, Ladislav Matějka, Lubomir Doležel, Thomas Pavel, Benjamin Hrushovsky, Andriej Piatigorski, Peter Steiner), upowszechniających „swoje” teorie w formie podręczników, antologii, monografii i długofalowych serii wydawniczych, polscy badacze literatury na uchodźstwie, którzy rozpoczynali w kraju działalność naukową z nastawieniem i dobrym przygotowaniem teoretycznym (Manfred Kridl, Zbigniew Folejewski, Wiktor Weintraub, Tymon Terlecki, Jan Kott, Stanisław Barańczak, poniekąd także Czesław Miłosz) ani nie kontynuowali tych zainteresowań, ani nie propagowali tak skutecznie, jak rosyjscy i czesko-słowaccy sąsiedzi, międzywojennego i powojennego polskiego dorobku teoretycznego. Z reguły poza uprawianiem doraźnej krytyki literackiej, wykazującej przy tym szereg ułomności wynikających z życia w kulturze izolowanej, środowiskowo tabuizującej ${ }^{16}$, skupiali się na wprowadzaniu do świadomości cudzoziemców historii literatury polskiej lub też - jako slawiści - prezentowali ją w ograniczonej perspektywie komparatystycznej, najczęściej w zestawieniu z literaturą rosyjską, która budziła znacznie żywsze zainteresowanie ${ }^{17}$. Naszymi ambasadorami byli Rosjanie (Jakobson) lub uczeni uznawani za Rosjan (Erlich) i Czesi (Wellek), dzięki którym w świecie anglojęzycznym w ogóle pojawiły się informacje o polskich międzywojennych kołach i szkołach, przedsięwzię-

15 Emigrujący do USA od lat. 30. uczeni europejscy, uciekinierzy przed kolejnymi falami nazizmu i antysemityzmu, ustalali nie tylko nasz kanon. Powstał wtedy także kanon modernizmu europejskiego w naukach społecznych, a także w sztukach plastycznych. Por. Migracje modernizmu: nowoczesność i uchodźcy, red. T. Majewski, A. Rejniak-Majewska, W. Marzec, Łódzkie Stowarzyszenie Inicjatyw Miejskich „Topografie” - NCK, Łódź-Warszawa 2014. Wędrówki ludzi, a wraz z nimi metodologii i terminów naukowych bodaj po raz pierwszy pół wieku temu z okładem opisał (w zakamuflowanym trybie autobiograficznym) R. Jakobson An Example of Migratory Terms and Institutional Models: On the Fifttieth Anniversary of the Moscow Linguistic Circle, w: tegoż Selected Writings, vol. 2, Mouton, The Hague 1971.

16 Por. J. Stradecki $O$ „Wiadomościach” londyńskich, w: Literatura źle obecna. Rekonesans, Polonia, Londyn 1984; K. Dybciak Literacka działalność Instytutu Literackiego, w: Literatura źle obecna.

17 Pisze o tym Wiktor Weintraub we wspomnieniach O współczesnych i o sobie. Wspomnienia, sylwetki, szkice literackie, red. S. Barańczak, Znak, Kraków 1994, s. 33-36. Diagnozę Weintrauba, pisaną w roku 1977, potwierdza w bez mała pół wieku później E.M. Thompson w gniewnym artykule Slavic but not Russian: Invisible and Mute, „Porównania” 2015 nr 16. 
ciach indywidualnych i zespołowych oraz o dokonaniach wybitnych uczonych, w tym także językoznawców, filozofów i antropologów. Nie inną niż czysto historycznoliteracka aktywność podejmowali badacze literatury zatrudniani na katedrach slawistycznych w Europie, którzy - jak Kridl, Marian Szyjkowski, Julian Krzyżanowski, Karol Wiktor Zawodziński - legitymowali się wcale poważnym dorobkiem teoretycznym. Także powojenne fale polskiej emigracji naukowej nie zatroszczyły się o migrację „Polish theory”, ani indywidualnie, ani instytucjonalnie ${ }^{18}$. Również w przeciwieństwie do kolejnych fal emigracji rosyjskiej i czeskiej, dzięki którym w Tel Aviwie rozwinęła się translatoryka, w Kanadzie teoria światów możliwych, a dzięki licznym francuskim, angielskim i niemieckim antologiom rosyjskiego formalizmu, zainicjowanym przez Todorova i Kristevą, Franco Moretti mógł zbudować swoją autorską historię literatury na Jakobsonie i Tynianowie ${ }^{19}$.

Okazja do wprowadzenia literaturoznawstwa polskiego na scenę światową wtedy, kiedy była ona dopiero aranżowana, dopiero się stabilizowała, została przegapiona. Późniejsze, z lat już 70.-90. tłumaczenia rozpraw polskich badaczy, choć stosunkowo liczne i publikowane w liczących się periodykach i oficynach, nie były w mocy naruszyć utrwalonego i reprodukowanego kanonu ani przywrócić im należnego miejsca.

Można tylko pomarzyć, co by było gdyby Andrzej Walicki napisał w Notre-Dame swój fundamentalny zarys nie rosyjskiej, ale polskiej myśli filozoficznej i społecznej. I umieścił w tym zarysie zarówno warszawską szkołę historyków idei, jak i działającą wespół z nią, w tej samej czasoprzestrzeni miejskiej i ludzkiej - warszawską szkołę strukturalną i jej międzywojenne antecedencje.

Nikłą aktywność literaturoznawczą polskich uczonych emigracyjnych można rozmaicie tłumaczyć: zatroskaniem o osobistą stabilizację, brakiem solidarnego wsparcia ze strony różnych emigracyjnych środowisk

18 "Kultura Paryska” propagowała myśl społeczno-polityczną, a londyńskie „Wiadomości” - literaturę i krytykę literacką. Także Polskie Towarzystwo Naukowe na Obczyźnie, w którym aktywnie działał Tymon Terlecki do wyjazdu do USA, choć początkowo miało oddzielny Wydział Humanistyczny, obejmujący filologię i językoznawstwo, nie podjęło aktywności proliteraturoznawczej. Być może jakąś rolę odegrały tu spory między instytucjami. Jakkolwiek było, publikacje były nastawione na polskiego odbiorcę emigracyjnego i krajowego, a nie międzynarodowego.

19 F. Moretti Wykresy, drzewa, mapy. Abstrakcyjne modele na potrzeby historii literatury [2005], przeł. T. Bilczewski, A. Kowalcze-Pawlik, Wydawnictwo UJ, Kraków 2016. Mówił o tym w maju 2015 roku Peter Steiner (sam - czeski emigrant) w wystąpieniu na konferencji zorganizowanej przez Stanford University „Russian Formalizm and New Digital Humanities", zatytułowanym Divergence vs. Convergence: Moretti, Tynianov, Jakobson (autorowi dziękuję za udostępnienie referatu). 
i konfliktami między nimi ${ }^{20}$, wyniesionymi z międzywojnia romantycznymi wzorcami polskości, które mogły zaspokajać potrzeby polonii, ale nie służyły propagowaniu nowoczesnej naukowej humanistyki polskiej.Zapewne także słabszym doświadczeniem emigranta-intelektualisty w porównaniu z myślicielami rosyjskimi, zaprawionymi w tej roli od pierwszych lat po rewolucji, toteż mniej skłonnymi do obrony wysokich standardów europejskiego akademickiego modernizmu. I umiejącymi opakować i sprzedać „swoje” tak, by zyskało atrakcyjność w oczach „innego"21.

Przypadkiem wyjątkowo klarownym pod tymi względami jest Manfred Kridl. O wiele lepiej obeznany z rosyjskim formalizmem niż autor pierwszej monografii szkoły, Victor Erlich ${ }^{22}$, a nadto doskonale zorientowany w tzw. polskiej szkole formalnej, jako jej współtwórca, i w strukturalizmie praskim, z którym „jego" grupa warszawsko-wileńska w drugiej połowie lat 30. intensywnie współpracowała, pilny czytelnik także nowszych prac młodoformalistów, uczniów Jurija Tynianowa i Borisa Ejchenbauma, o których to on informował doktoranta Jakobsona, udzielając mu konsultacji ${ }^{23}$, był najlepiej przygotowany do napisania tej monografii. Skończyło się na wykładach dla studentów ze „słowiańskiej” (tak!) teorii literatury - znakomitych, bardzo szczegółowych, informujących nie tylko o rosyjskim i czesko-słowackim nowoczesnym literaturoznawstwie międzywojennym, ale także obszernie o dziejach literaturoznawstwa polskiego ${ }^{24}$ - na propagowaniu ich na spotkaniach

20 Por. wymowne dokumenty z archiwum PIASA w Nowym Jorku zebrane i opracowane przez Beatę Dorosz, Kazimierz Wierzyński w kręgu Polskiego Instytutu Naukowego, "Zeszyty Naukowe Uniwersytetu Rzeszowskiego", Seria Filologiczna 2011, z. 70.

Świadomość Jakobsona ważności takiego działania manifestuje już jego artykuł opublikowany pod pseudonimem Aljargow, Zadaczi chudożestwiennoj propagandy, "Iskusstwo" $1919 \mathrm{nr} 8$ (Moskwa, nr z 5 września); artykuł odnotowywany w bibliografiach, ale nie włączony do "Selected Writings"; publikacja Aleksandra. E. Parnisa w: R. Jakobson Raboty po poetikie, wstupitielnaja stat'ja Wiaczesława Iwanowa, sostawlenije i obszczaja riedakcyja Michaiła Gasparowa, Moskwa 1987.

V. Erlich Russian Formalism: History - Doctrine, London-The Hague-Paris 1955. Erlich rozpoczynał doktorat pod kierunkiem Arthura P. Colemana, ostatecznie ukończył dysertację pod opieką Jakobsona.

23 Informacje na podstawie korespondencji Kridla z Erlichem zachowanej w archiwum Kridla w Rare Books \& Manuscripts Library na Columbia University (dalej RBML): RBML, Manfred Kridl Papers, Series II, Box 3 .

24 Zachowane konspekty wykładów i notatki do nich wskazują, że Kridl prezentował dzieje polskiej myśli literaturoznawczej od Szymona Starowolskiego poczynając. Wymowne jest omówienie rozprawy Brodzińskiego O klasyczności i romantyczności, za której główną ideę Kridl 
studenckiego koła naukowego, które wzorem międzywojennych kół warszawskiego i wileńskiego założył na Columbia University ${ }^{25}$, i jednym bodaj artykule o formalizmie - poświęconym jednak wyłącznie formalistom rosyjskim² ${ }^{26}$. W roli znawcy szkoły wyprzedził go nie tylko Erlich, ale i Renato Poggioli, autor hasła „formalizm rosyjski” w powszechnie cenionym słowniku Shipleya. Nie doszło także do angielskiego wydania Wstęu do badań nad dziełem literackim, o które intensywnie zabiegał, bacznie obserwując otoczenie i dobrze zdając sobie sprawę, że nie wykłady uniwersyteckie przeznaczone dla małego grona słuchaczy, ale przekłady oraz opracowania monograficzne mogą,,wprowadzić nasze badania nad teorją literatury i metodologią na szersze wody". Wzory, na które się powoływał, były dobre: „W dziedzinie badań literackich musimy postępować tak, jak postępują polscy matematycy i jak postępuje właśnie «Cercle Linguistique de Prague», t. j. wydawać prace w językach obcych i wciągać do współpracy jak najwięcej uczonych cudzoziemskich"27.

Dlaczego bez powodzenia? Z korespondencji z Wellekiem jasno wynika, że Kridl nie został najlepiej przyjęty przez „słowiańskich” literaturoznawców emigracyjnych, że spotykał się z ich strony z protekcjonalnym lekceważeniem i bezpardonową krytykąa ${ }^{28}$, wyraźnie postrzegany jako konkurent do

uznaje "Let us not to be the echo of the foreigners"; RBML, Manfred Kridl Papers, Series III, Box 7, teczka "Lectures on Slavic literary theory, Columbia University".

Koło oficjalnie zainaugurowało działalność 7 marca 1949 roku, w 150. rocznicę urodzin Mickiewicza, jak informuje list Kridla (RBML, Manfred Kridl Papers, Series III, Box 17, t. 1); w t. 2 zachowały się protokoły posiedzeń i spotkań otwartych, prowadzone skrupulatnie od 1948 do 1955 roku (pierwszą protokolantką była doktorantka Kridla, Olga Scherer-Virski).

Russian Formalism, "The American Bookman” 1944, I, s. 10-30. Publikacja miała długą historię, łączącą się ze sporami z Wellekiem, który długo przetrzymywał artykuł, zapewniając, że stara się go wydrukować w którymś z periodyków uniwersyteckich, a gdy wreszcie tekst się ukazał (w nieliczącym się czasopiśmie) - skwitował zimno, że jest spóźniony, bo właśnie wyszedł "a small article on the Russian formalism by R. Poggioli in Shipley's Dictionary of World Literature" (list z 10 kwietnia 1944 roku; RBML, Manfred Kridl Papers, Series II, Box 2).

27 Brudnopis listu z 5 listopada 1942, odpowiadającego na postulaty sformułowane na posiedzeniu z 20 lipca "podkomisji dla prac na przyszłość Mieszanego Polsko-Czechosłowackiego Komitetu Współpracy Kulturalnej", które odbyło się w Czechosłowackim Ministerstwie Spraw Wewnętrznych, RBML, Manfred Kridl Papers, Series II, Box 3. Kridl zabiegał nie tylko o przekład swojej rozprawy, ale też o poparcie Jakobsona i Weintrauba oraz uzyskanie funduszy na wydanie dysertacji swojej doktorantki, Olgi Scherer-Virsky (po różnych perturbacjach praca w końcu została opublikowana; O. Scherer-Virsky The Modern Polish Short Story, Mouton, S.-Gravenhage 1955). 
slawistycznego kondominium. Sytuację nadto komplikował fakt, że był także nie najlepiej, mówiąc oględnie, widziany w środowisku emigracji polskiej. Zajmowaną przez niego katedrę finansował rząd PRL, był łączony z Miłoszem - od 1945 roku konsulem polskim w Nowym Jorku, a od 1946 attaché kulturalnym w Waszyngtonie, co dawało powody do pomówień o komunistyczną agenturę ${ }^{29}$. Bywał wplątywany w toczące się spory polityczne, choć starał się ich unikać i nie wdawał się w „martyrologiczne”, jak je interpretował, wydarzenia naukowe ${ }^{30}$. Ulegał jednak „martyrologicznej” poetyce wydarzeń

rych sam wyraźnie nie rozumie, bo proponuje, by Erlebte Rede oddać przez interior monologue albo stream of consciousness), niestosowne tytuły referatów, które sam zmienia, wypaczając ich sens, i kwestionując nazwy dyscypliny (np. proponowany przez Kridla temat "The integral method of literary scholarschip" zastępuje samowolnie przez "Integral Literary History"). Z drugiej strony korespondencja ujawnia nader słabe, nieporównywalne z Kridlowym rozeznanie Welleka w literaturoznawstwie teoretycznym środkowo- i wschodnioeuropejskim, wciąż proszącego o jakieś wskazówki i dane bibliograficzne. Kridl musiał silnie odczuwać manifestowaną przez Welleka wyższości, tym bardziej dotkliwie, że wyjaśniał Wellekowi elementarne dosłownie kwestie, np. o pochodzeniu i znaczeniu Erlebte Rede czy o polskim baroku, gdy ten (z przechwałką) „poinformował o pisaniu komparatystycznego artykułu o pojęciu baroku w różnych kulturach i poprosił o radę w sprawie baroku polskiego, o którym niewiele wiedział.

29 W zbiorze listów do Kridla zachował się anonim z 16 stycznia 1956 r., przestrzegający go przed działaniami PIASA i Ludwikiem Krzyżanowskim, który miał publicznie oznajmiać, że tylko "his Academy was the only one true patriotic manifestation in the spirit of Free Poland unlike the Memorial arranged by you as a stooge of the Polish Communistic Government under the patronage of the Slavonic Department at Columbia University". Krzyżanowski miał także oskarżać całą slawistykę na Columbia University o propagowanie komunizmu, uznając Jakobsona i Kridla za poputczików ("the com. propaganda at Columbia was the Slavonic department dominated by two Russian Jews, fellow travelers"), a Kridla nadto - o pobieranie pensji od "the Polish red government", RBML, Manfred Kridl Papers, Series II, Box 3. Nawet Olga Scherer-Virsky, złożyła rezygnację z funkcji sekretarza Koła Polonistów, motywując decyzję tym, że w Kole są ludzie popierający PRL, i protestując przeciwko planom zaproszenia na prelekcję Stanisława Ossowskiego (RBML, Manfred Kridl Papers, Series II, Box 4). Trzeba jednak pamiętać, że był to czas działalności senackiej komisji McCarthy'ego, która od 1950 roku prowadziła śledztwa w sprawie antyamerykańskiej, finansowanej przez organizacje komunistyczne działalności emigrantów, także przeciwko Jakobsonowi, uczestnicy zdarzeń mogli więc ulec indoktrynacji.

Świadczy o tym korespondencja towarzysząca przygotowywaniu antologii The democratic heritage of Poland: "For your freedom and ours": an anthology, ed. by M. Kridl, J. Wittlin, W. Malinowski, G. Allen \& Unwin, London 1944. W liście z 28 kwietnia 1944 roku Kridl zaznacza, że wybór ma charakter neutralny i sam nie chce wchodzić w spory, czy ma się w nim znaleźć Pruszyński, czy Ciołkosz, Zahorska lub Hertz, wyjątek czyniąc jedynie dla Słonimskiego, jako konsekwentnie zajmującego stałe stanowisko - "czego, niestety, nie można powiedzieć o innych autorach", RBML, Manfred Kridl Papers, Series II, Box 3. Nb. Kridl proponował, by okładkę zaprojektowała Teresa Żarnowerówna, wtedy na emigracji w Nowym Jorku i podobnie, jak on, marginalizowana w środowisku uchodźców europejskich. O nastawieniu Kridla do prezentowania twórczości 
kulturalnych, niewładny przeciwstawić się stanowiskom, które zajmowała „przytłaczająca większość tzw. luminarzy na emigracji”, żyjących „w fanta-

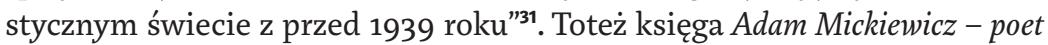
of Poland ${ }^{32}$ nie spełniła pokładanych w niej nadziei Czesława Miłosza i Józefa Wittlina. Ostrożny Kridl zajmował postawę zachowawczą, by nie narażać się obu nieprzyjaznym środowiskom.

No i znacznie gorzej znał język angielski niż anglista Wellek...

W tej sytuacji Kridl poprzestał na aktywności dydaktycznej i popularyzatorskiej $^{33}$. Prowadził zajęcia na temat literatury polskiej dawnej i nowszej, historii języka polskiego, literatur słowiańskich w XIX wieku i folkloru. Nie tylko przewidywalne, schematyczne. Pośród podjętych zagadnień, zapewne ustalanych z władzami uczelni, zaskakująco nowatorski, w zamyśle kulturoznawczy, a nie historycznoliteracki jest kurs z 1953 roku poświęcony Modern Polish intellectual history. Kridl precyzyjnie zdefiniował w nim pole i przedmiot badań, który uznał za nadrzędny wobec "scholarschip (sciences and humanities), intellectual trends in philosophy (prądy umysłowe), polit. and social thought, moral problems, religion, sociology, education", starał się także doprecyzować i uzgodnić polskie i angielskie znaczenie modern ${ }^{34}$. Manuskrypt tych zajęć wskazuje na nieporównywalnie szerszy projekt naukowy niż propedeutyczna Literatura polska (na tle rozwoju kultury), wydana także po angielsku ponad dziesięć lat później. Tylko jednak zajęciami dla studentów

polskiej w duchu martyrologii narodowej świadczy odrzucenie zaproszenia do wygłoszenia wykładu na uniwersytecie w Brukseli "Le martyrologie de la litterature polonaise", na które odpowiedział: „Rozumieją Panowie, że ja do takiej «martyrologii» ręki przykładać nie mogę” (list z 7 kwietnia 1943 r.; RBML, Manfred Kridl Papers, Series II, Box 3). Ważniejsze wydaje się jednak, że rezygnując z wykładu, Kridl wskazywał na nierównorzędność udziału badaczy "słowiańskich" w zaplanowanym cyklu, wśród których rosyjscy mieli przydzielone 17 wykładów, czescy - 9, podczas gdy literaturę polską miałby reprezentować wyłącznie on.

Czesław Miłosz, list do Manfreda Kridla z grudnia 1954 roku, w: Cz. Miłosz „Mój wileński opiekun": listy do Manfreda Kridla (1946-1955) z uzupełnieniem o listy Manfreda Kridla i addendum, red. A. Karcz. Wydawnictwo UMK, Toruń 2005, S.12.

Adam Mickiewicz - poet of Poland: a symposium, ed. by M. Kridl, Columbia University Press, New York 1951. Patrz też o tym A. Karcz Refleksja nad literaturą w polskim piśmiennictwie emigracyjnym: Tymon Terlecki, Czesław Miłosz, Gustaw Herling-Grudziński, Wydawnictwo IBL PAN, Warszawa 2017, s. 165 i 223.

Tak też tłumaczy nikłą aktywność naukową Kridla Tadeusz Bujnicki Manfred Kridl i rosyjska "Szkoła formalna", „Pamiętnik Literacki" 1987 z. 1. 
pozostały. Przygotowywana anglojęzyczna antologia literatury polskiej i starania - bezskutecznie - o publikację swojego podręcznika do historii literatury nie miały już takiego nowatorskiego charakteru ${ }^{35}$. Opinie wydawców z Columbia University i koedytora z Leiden o tym ostatnim były miażdżąco krytyczne, i ze względu na ułomności języka, i przede wszystkim - rozmijanie się wysoce specjalistycznej rozprawy pisanej zgodnie ze standardami europejskimi z zapotrzebowaniami odbiorców wychowanych w innej kulturze naukowej.

Kridl wyraźnie nie radził sobie w roli emigracyjnego uczonego tak dobrze, jak nie tylko okrzepły w niej Jakobson, który potrafił zafascynować inny, amerykański świat nawet literaturą staroruską, ale także Wellek, który nawiązał świetny kontakt z grupą tzw. krytyków z Południa i we współautorstwie z Austinem Warrenem w latach 1944-1946 napisał doskonale funkcjonujący nie tylko w USA podręcznik do teorii literatury ${ }^{36}$. Kridl tymczasem nie dość, że słabo orientował się w zasadach rządzących amerykańskim rynkiem idei, próbując sił już to jako autor artykułu o twórczości Erskine’a Caldwella, już to proponując do realizacji scenariusz filmu na podstawie Faraona bez wiedzy o prawach autorskich do istniejącego od 1902 roku przekładu powieści ${ }^{37}$, to nadto był chyba autentycznie zagubiony w nowym świecie i w nowej powojennej rzeczywistości politycznej, w której i przed wojną rozeznawał się nie najlepiej. Patrzył na nią z wyżyn ideałów liberalnego demokraty ${ }^{38}$, a emigrację po wybuchu wojny traktował wyraźnie jako tymczasową konieczność. Że przeminie i świat powróci do swoich kolein, świadczą wymownie dwa kalendarzyki. W notatkach z roku 1938 ze spisem rzeczy, które należy zabrać w wakacyjną podróż po Grecji, widnieje „czarna torebka z brylancikami”.

35 M. Kridl Literatura polska (na tle rozwoju kultury), Roy Publishers, New York 1945; A Survay of Polish Literature and Culture, transl. from the Polish by O. Scherer-Virsky, S-Gravenhage:Mouton, New York 1956; An Antology of Polish Literature, edited with English commentary and notes, Columbia University Press, New York-London 1957.

R. Wellek, A. Warren Theory of Literature, Harcourt, Brace, New York 1949.

RBML, Manfred Kridl Papers, Series III: Manuscripts, Box 13, teczka zatytułowana „Pharaoh screenplay (with related correspondence); manuskrypt obejmujący 136 stron formatu $A_{4}$ jest częściowo przepisany na maszynie (13 stron).

Choć naturalnie nie był nieświadomy konfliktów etnicznych w Wilnie. Gdy np. poznaniacy postawili warunek wileńskim organizatorom planowanego na 1937 rok zjazdu naukowych kół studenckich, by nie było na nim referentów żydowskich, a wilnianie warunek przyjęli, Kridl interweniował u rektora Uniwersytetu Stefana Batorego, który udzielił wilnianom surowej nagany. Por. T. Dalecka Dzieje polonistyki wileńskiej 1919-1939, Kraków 2003: TNSV, s. 172. 
Ta sama torebka (a nadto „,szal fokowy”, ,szkatułka belgijska” i sztućce wyliczone co do typu i liczby) znajduje się w spisie rzeczy do zabrania na emigrację z 1940 roku 39 .

We wszystkich emigracyjnych publikacjach Kridl trwał z uporem przy wysokich normach akademickiego literaturoznawczego modernizmu, nie godząc się na najmniejsze zmiany w swoich tekstach (np. na wyeliminowanie terminu „ergocentryzm”, nic niemówiącego uczonym w USA, lub zastąpienia swojej „metody integralnej” przez lepiej zrozumiałe „a purist theory of literary history" lub "theory of integral literary history") ${ }^{40}$. Nie był odosobniony. Na rynku amerykańskim nie odnalazł się Bertold Brecht, z trudem poruszali się po nim emigranci ze szkoły frankfurckiej. Modernizmy amerykański i europejski, zarówno w sztukach, jak i w naukach humanistycznych, dzieliła przepaść. Jakkolwiek to oceniać, faktem pozostaje, że szansa, jaką miał, na wprowadzenie literaturoznawstwa polskiego na aranżowaną dopiero scenę literaturoznawstwa światowego, została zaprzepaszczona.

Przegapiona ongiś okazja nie przepadła bezpowrotnie. Jej podjęciu sprzyjają ostatnie dekady zmian w literaturoznawczym „teatrze mowy”.

Leżące odłogiem w polu nowoczesnego literaturoznawstwa teoretycznego studia polskie można z powodzeniem zagospodarować. Długoletnia nieobecność i po prostu nieznajomość teorii polskich wytworzyła dogodne warunki dla wypracowania alternatywnego ujęcia historii dyscypliny i wprowadzenia do obiegu kanonu suplementarnego. Nie reparacyjnego „antykanonu” bądź „postkanonu" ${ }^{41}$, które powstają w reakcji na niebyłość kultur zsubordynowanych, ale właśnie kanonu - suplementu. Nawet gdyby miał pozostać jedynie apendyksem, jeśliby zaistniał choćby tylko na zasadzie „retrospektywnej funkcjonalności" ${ }^{\prime 2}$, powinien przynajmniej wywołać dyskomfort i wymusić krytyczną refleksję o literaturoznawczych kanonach uznanych.

40 Propozycje w liście z 27 maja 1948 na papierze firmowym periodyku "Comparative Literature. A Quarterly Journal Published by the University of Oregon"; RBML, Manfred Kridl Papers, Series II, Box 6, t. 1.

B. Bakuła Kanon, antykanon, postkanon w dyskursie o tożsamości kultur w Europie Środkowej iWschodniej, „Porównania” $2011 \mathrm{nr} 9$.

42 J. Zieliński Kłącza - (kłonice) - synapsy (Posłowie), w: A. Wat Notatniki, transkr. i oprac. A. Dziadek, J. Zieliński, Wydawnictwo IBL PAN PAN - Wydawnictwo UŚ, Warszawa-Katowice 2015, s. 895 . 
Ustanowieniu suplementu sprzyjają i inne okoliczności: rosnący wzrost zainteresowania dla historii wiedz, przemiany w ich uprawianiu, polegające na wydobywaniu niekonieczności zastanych ujęć i, w kontrze do deterytorializacji, ich sytuowaniu w kontekstach geopolitycznych oraz na równouprawnianiu różnych świadectw (listów, wspomnień, anegdot); odkrywanie obszarów lokalnych i regionalnych towarzyszące studiom „światowym” i transkulturowym, z pogłębioną refleksją nad niestałością hierarchii dominujące - podporządkowane i krytycznymi uwagami o asymetrii stanu wiedzy o tych obszarach w nauce globalnej, a i zwykłej niewiedzy o nich.

Tę korzystną naukoznawczą sytuację ogólną wzmacniają zmiany w polu samej teorii. Po półwiecznych debatach o jej „końcu” i nawet „śmierci”, o antyteorii i postteorii, które poświadczają przecież ni mniej, ni więcej, tylko teorii żywotność, niepogrzebanej mimo funeralnych proklamacji, nastaje wyraźnie czas powrotu do teorii, która „waży"43 i ,zawsze spada na cztery łapy”44. Na naszych oczach powstaje „teoria po teorii",,teoriateorii” [Theorietheorie] ${ }^{45}$. Wytarte jak żetony prefiksoidy „anty” $\mathrm{i}$,post" znalazły zamiennik - „proto"46, wskazujący na niewyzyskany potencjał przeszłości: na teoretyczne nieużytki i na te aspekty teorii spatynowanych, które pozostały niewydobyte.

Wskrzeszana teoria nie jest więc tą samą teorią, którą zadekretowały kompendia propedeutyczne w połowie wieku XX i przeciwko której wymierzony był cały ruch anty- i post. Przyjęcie perspektywy „proto" prowadzi najpierw do redefinicji teorii, takiej, która pozostawałaby w zgodzie z rzeczywistymi praktykami badawczymi, a nie z intelektualną doksą.

Dla teorii polskiej sytuacja jest tym jeszcze dogodniejsza, że - jak wiele wskazuje - wyczerpała się atrakcyjność doksograficznego kanonu ${ }^{47}$. A że

Określenie "matters" - waży - z zastanawiającą częstością powtarza się w tytułach najnowszych artykułów i kompendiów literaturoznawczych, by przywołać: Theory Matters. The Place of Theory in Literary and Cultural Studies Today, ed. by M. Middeke, Ch. Reinfandt, Palgrave Macmillan, London 2016.

44 J. Elliott, D. Attridge Theory's nine lives, w: Theory after 'Theory', ed. by J. Elliott, D. Attridge, Routledge, London-New York 2011.

45 N. Birns Theory after Theory. An Intellectual History of Literary Theory From 1950 to Early 21st century, Broadview Press, Toronto 2010; Theorietheorie: Wilder die Theoriemüdigkeit in der Geisteswissenschaften, Hg. M. Grizelj, O. Jahraus, Fink, München 2011.

47 Np. w trzecim wydaniu antologii Literary Theory (ed. by J. Rivkin, M. Ryan, Blackwell, Malden MA 1998) formalizm rosyjski, jeszcze w edycjach 1. i 2. reprezentowany kilkoma tekstami, został zredukowany do jednego artykułu - Szkłowskiego Sztuka jako chwyt, a czeskiego strukturali- 
w rosyjskim i czeskim „sąsiedztwie" zaczynają powstawać jego alternatywy ${ }^{48}$, dla wprowadzenia kanonu suplementarnego, obejmującego nowoczesne literaturoznawstwo polskie, koniunktura robi się wyjątkowo korzystna.

\section{Abstract}

\section{Danuta Ulicka}

UNIVERSITY OF WARSAW

\section{A Missed Opportunity}

Ulicka tackles three related issues: the apparently peripheral status of Polish literary theory, its absence from the global canon, and the mechanisms behind this state of affairs. The first issue is addressed in terms of the (re)transfer of concepts in literary scholarship, the second in terms of knowledge reproduction, while the third issue is discussed with reference to the processes of canon formation and of achieving success and authority in academia - processes described by scholars of agnotology. To provide an example Ulicka discusses documents from the archive of literary scholar Manfred Kridel. She presents an optimistic view of building an alternative and supplementary canon in which "Polish theory" would find its rightful place.

\section{Keywords}

agnotology, transfer, knowledge reproduction, emigration, the Slavic condominium, supplementary canon

zmu nie ma w ogóle, choć strukturalizmowi poświęcony jest rozdział drugi. Podobnie redukowany jest kanon, wyraźnie uznany za zużyty, w wielu innych kompendiach.

48 Wydana w 2016 roku trzytomowa antologia rosyjskiego formalizmu obejmuje rozprawy dotąd nigdy nieuwzględniane. W t. 1., oprócz kanonicznych artykułów Szkłowskiego, znalazły się m.in. teksty Kazimierza Malewicza o bezprzedmiotowości, Siergieja Eisensteina o montażu, Aleksieja Gana o tektonice; w t. 2. - oprócz Ejchenbauma - studia Dizgi Wiertowa, Siergieja Trietjakowa i Warwary Stiepanowej; w t. 3- oprócz Jakobsona i Brika - także prace El Lisickiego, Wsiewołoda Meyerholda i Władimira Tatlina (Formalnyj mietod, t. 1 - Sistiemy, t. 2 - Matieriały, t. 3 - Tiechnołogii, ried. Siergiej Uszakin, Moskwa - Jekatierinburg 2016: Kabinietnyj uczonyj. 